\title{
Contributions from the Philosophy of Science to the Education of Science Teachers
}

\author{
VICENTE MELLADO ${ }^{1}$, CONSTANTINO RUIZ $^{1}$, \\ MARÍA LUISA BERMEJO ${ }^{2}$ and ROQUE JIMÉNEZ ${ }^{3}$ \\ ${ }^{1}$ Department of Science and Mathematics Education, Faculty of Education, University of \\ Extremadura,Badajoz, Spain (E-mail: vmellado@unex.es); ${ }^{2}$ Department of Psychology and \\ Sociology of Education, Faculty of Education, University of Extremadura, Badajoz, Spain; \\ ${ }^{3}$ Department of Science Education and Philosophy, Faculty of Education, University of Huelva, \\ Spain
}

\begin{abstract}
One of the most important topics on the international agenda in educational research is to gain an understanding of the processes of educational change in teachers and of the factors that favour or hinder it. Such understanding is, for instance, an essential element in planning and putting into practice initial and ongoing teacher education programs. This article reviews the research on science teachers' educational change. To organize the information, an analogy is made with the process of scientific change, analyzing and evaluating the contributions of the different models taken from the philosophy of science - positivism, Popper's principle of falsifiability, Lakatos' scientific research programs, Laudan's research traditions, Toulmin's evolutionism, and Kuhn's relativism. We conclude the article with the implications for science teacher education.
\end{abstract}

\section{Introduction}

While we live in a time of accelerating change, of societies made interdependent by economic globalization and the development of information systems, there remain world-wide the problems of the environment, overpopulation, war, terrorism, inequality, poverty, and the endemic diseases of many parts of the planet. There is still a long way to go before globalization affects such important aspects as health, justice, education, sustainable development, or the spread of democracy. Also, many of the moral, political, and cultural tenets of the XX century are changing, and it is still not clear in which direction.

These changes have their reflection in the school (Marcelo 2002) which is becoming ever more complex and heterogeneous, as are the pupils themselves and the social context in which the school is a part. Longer obligatory schooling, growing interculturality, conflictiveness in the classroom, the loss of teachers' traditional role of authority, and the new 
technologies which give the pupils access to many sources of information and communication, represent a constant challenge to teachers many of whom find a mismatch between what was taught them in their professional education and what is actually expected of them.

Educational systems attempt to adapt to these changes by imposing curricular reforms while conserving the old organizational structures, ingenuously expecting that curricular change will suffice to improve teaching. It is not taken into account that the key to the qualitative improvement of educational systems are the teachers themselves, and it is they who truly determine the success or failure of any reform or curricular innovation (Mitchener and Anderson 1989; Tobin et al. 1994). As noted by Fullan (1991, p. 117) "changes in education depend on what teachers think and do, something at once so simple and so complex". Teachers are not technicians limited to applying the reforms and instructions drawn up by the experts. Rather they have values, attitudes, and conceptions, and make decisions on the basis of many factors, including their own history and personal situation, and the social and professional context in which they work. This complexity means that, unless particular attention is paid to teacher education and change, educational reforms have little influence on life in the classroom.

An important topic in research on teacher education and professional development is the process of change in science teachers considered in its various stages, and the factors that favour or hinder it (Abell and Pizzini 1992). Our purpose in this article is to attempt to understand this process in which, in one way or another, all of us as teachers are immersed, and thereby enable us to come to rational decisions on what should be changed and what should be kept or improved. Our basis will be models that are analogues of the different models of scientific change from theories of the philosophy of science (Mellado 2003). We shall conclude the article with the implications for science teacher education.

\section{An Analogy between the Philosophy of Science and Educational Change in Science Teachers}

Until the 1980s, the philosophy of science was practically absent from both science teaching programs and teacher education. Instead, there was an implicit acceptance of immature and untested conceptions of the nature of science (Burbules and Linn 1991). Many works then began to consider that it was indispensable to include some reflection on the nature of science in science teaching programs and teacher education (Matthews 1992). Despite the best intentions, however, there are still many impediments against 


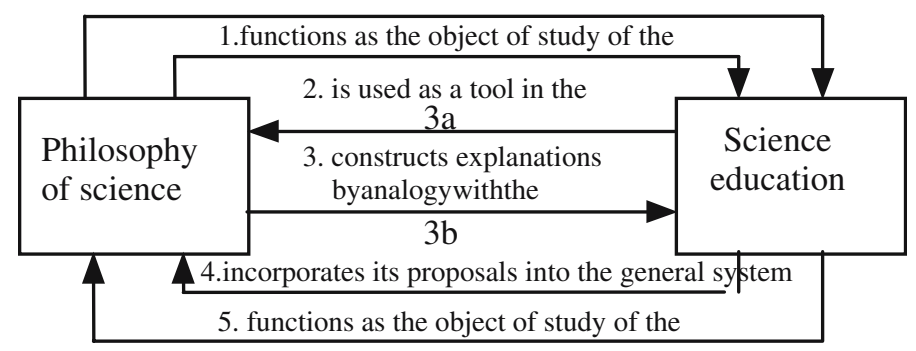

Figure 1. Relationships between science education and philosophy of science (Adúriz-Bravo 2001, p. 487).

science teachers receiving good instruction in the history and philosophy of science (Matthews 2004a).

There have been numerous lines of research relating the philosophy of science with science teaching. Adúriz-Bravo (2001) groups these relationships into seven classes. Two refer to the objects of study shared by the two disciplines - the epistemological foundation of erudite science, and the epistemological foundation of school-level science. The other five refer to the relative positions taken by educational and philosophical metadiscourse (Figure 1).

One of these research lines constructs explanations of an analogical nature for science teaching on the basis of the models and theories of the philosophy of the science (3a of Figure 1). Indeed, since Piaget (1970) set out a parallel between scientific progress and the psychological process of the development of the child, analogy with models in philosophy has been used as a basis for theories of learning science and of pupils' conceptual change (Nussbaum 1989; Clemison 1990; Burbules and Linn 1991; Cobb et al. 1991; Mellado and Carracedo 1993; Cudmani et al. 2000; Villani 2001). In this present article, we shall analyse the processes of change in the science teacher by establishing an analogy between scientific change according to different philosophical theories and the change in teachers' educational practice.

An analogy is a comparison between two situations or different domains of knowledge that have a certain similarity relationship with each other (Bermejo et al. 2002). Constructivism, as also Piaget's notion of equilibration or schema theory, considers meanings to be constructed actively, relating the new with ideas that are already held via a generally analogical process. Science itself commonly uses analogues in the context of discovery to understand the natural world, many of which remain long after their immediate usefulness. And every expert teacher knows the effectiveness of good analogies in the science classroom. 
An analogy is neither an equivalence nor a justification, but a comparison between two essentially different domains. Analogical learning, used with suitable limitations, has an enormous potential for building, relating, and organizing new knowledge on the basis of what is already known. While the establishment of analogies between scientific change and personal cognitive change is not exempt from criticism, it has the advantage of relating different scientific fields in a common endeavour, thereby acting as an antidote against the progressive specialization in research and the potential Balkanization of the different fields of research in the social sciences (Gilbert 1999).

Of the many criteria for classifying different philosophical theories (Vázquez et al. 2001), we shall take that which refers to the conditions that cause change and scientific progress. To this end, we selected a set of theories, on the basis of which we shall set up analogies with teachers' educational change. These theories are: positivism, Popper's principle of falsifiability, Lakatos' scientific research programs, Laudan's research traditions, Toulmin's evolutionism, and Kuhn's relativism. It is not our purpose to go to any depth into the enormous richness and complexity of philosophical theories. The objective is rather to make a schematic approach to how they deal with scientific progress and change in theories (Estany 1990) with the sole purpose of setting up the analogy.

\section{Positivist and Falsifiability Models}

Throughout the history of philosophy there has been constant tension in the fundamentals of scientific knowledge between the rationalist and the empiricist schools. The rationalist school stresses the importance of reason and the concepts created by the mind in the process of forming the foundations of scientific knowledge. Classical empiricism, however, stresses the justification of knowledge on the basis of data obtained directly from sensory experience, and deals with establishing an inductive scientific method supported on the data of that experience. The methodology of the 'narrow' inductivist conception of scientific research, in the words of Hempel (Estany 1993), can be summed up in the following steps: (1) observing and recording the facts; (2) analyzing and classifying them; (3) using them as the basis for the inductive derivation of generalizations; and (4) the subsequent testing of those generalizations.

During the 1920s and 1930s, the components of the Vienna Circle rejected dogmatism, and, with their different origins and academic backgrounds, attempted to provide a rigorous foundation for scientific knowledge, whose implications, both philosophical and educational, are still the object of a debate necessary today so as not to fall into simplifications 
about what this movement meant (Matthews 2004b; Philipp 2004). The empiricist school had an important influence in the first years of the Vienna Circle in its so-called logical positivism - instrumentalist and phenomenalist. These years were characterized by the rejection of metaphysics as a science, the development of mathematical logic, and the empirical and direct inductive verification of observational statements (Vázquez et al. 2001). Although logical positivism dealt with the context of the justification and not with discovery, so that one cannot properly speak of a change of theories, it regarded scientific progress as taking place by the accumulation of knowledge when there exists experimental verification of a new theory. This new theory has to maintain the confirmed predictions of the previous theory, incorporate new predictions which were not shown by that old theory, and avoid its false consequences.

The corresponding educational analogy with the accumulative conception of knowledge is the model of technical rationality (Figure 2). This considers that there is nothing problematic about change since teachers will change when they attend quality courses in which they are transmitted the most appropriate content and the best way of teaching it as verified by experts. For the in-service teacher, ongoing education based on courses given by experts is normally not very effective, except for a minority of courses with which the teacher shares the theoretical framework and discourse and hence is already willing to accept change. Teachers are usually

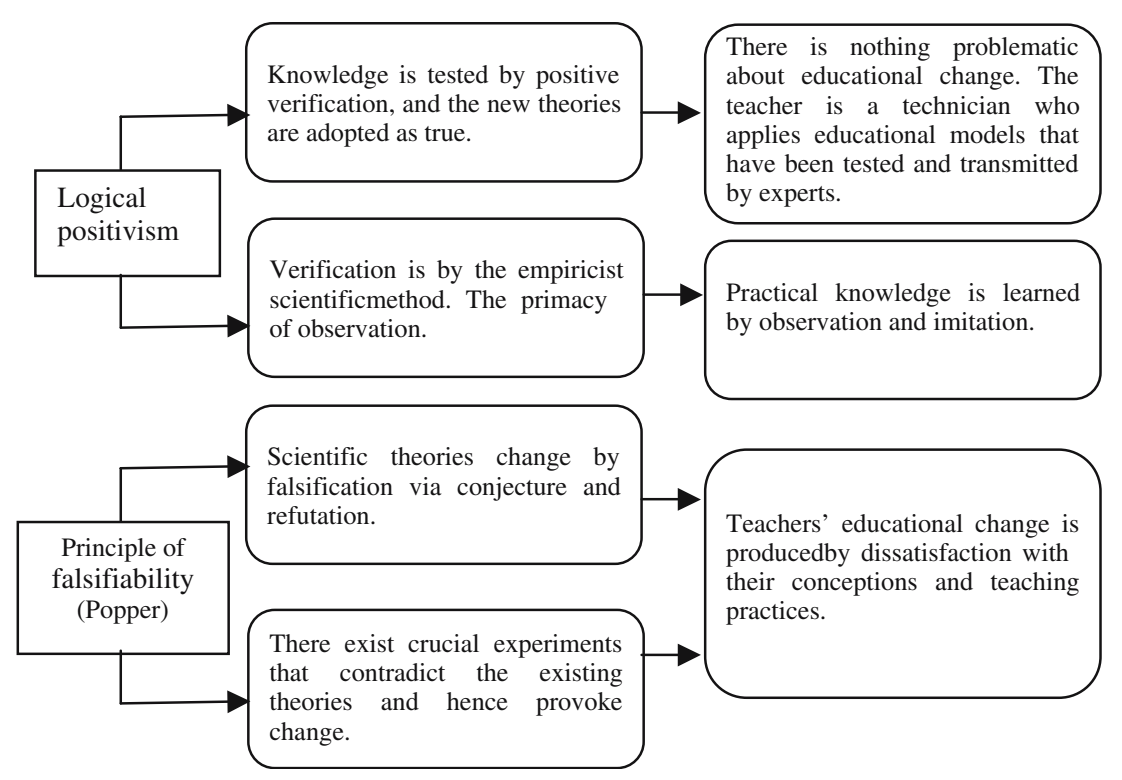

Figure 2. Analogy with logical positivism and Popper's principle of falsifiability. 
fairly skeptical about the reforms and ideal teacher models that are transmitted to them at any given time. They think that one can be a good teacher using very different teaching styles and strategies (Wildy and Wallace 1995). Thus, these teacher education strategies have not been at all effective in changing teachers' conceptions, and even less so their teaching practices, and when changes do occur it is more from the discussion and collaboration between the participants than from experts transmitting new models to them (Garret et al. 1990).

Paradoxically, this model of academic-propositional knowledge often co-exists in initial teacher education, but as two separate and independent parts, with a craft orientation towards the practice of teaching, based on inductive empiricism, which considers that practical knowledge of teaching is learned by one's own experience, by trial and error, and by the mere observation and imitation of expert teachers.

At university, hardly any attention is paid to the pedagogical education of the future university teacher. Indeed the empiricist conception predominates, and one finds fairly commonplace the simplistic conception that teaching is easy, and that to be a teacher it is enough to have knowledge of the material to be taught, experience, common sense, and innate personal qualities (Gil-Pérez et al. 1991; Perales 1998). The academic reward system is clearly coherent with this conception, being focused on research with little evaluation of teaching and few incentives to teach well.

Inductivist empiricism was rejected by many components of the Vienna Circle, and positivism evolved towards an orientation that stressed the role of hypotheses, and recognized that observation depended on theory. The principle of verification was maintained, but the validation of empirical statements would not be at the beginning, but a posteriori through empirical verification of the hypotheses by checking the conformity of a predicted fact with an observed fact (Kraft 1977).

Critical realism, Popper (1983), rejects principle of empirical induction, and emphasizes the value of theories as against observation. For Popper, a theory does not change by verification, but by falsification when a crucial experiment is found that contradicts it. Scientific progress occurs through the repeated overthrow of theories by falsification and their temporary replacement by other more satisfactory theories in a process of successive conjecture and refutation.

Analogously, change in teachers would be produced by dissatisfaction with their conceptions and teaching practices as against others considered more suitable (Figure 2). Nevertheless, although dissatisfaction are necessary elements for change (Ritchie and Rigano 2002), they are not sufficient, since the teacher may well continue living and working with 
unresolved conflicts and dilemmas (Hashweh 2003). Gil-Pérez (1993) considers the strategy of provoking dissatisfaction from outside to be 'perverse' in the sense that the intention is to make teachers' ideas and educational strategies explicit only to immediately reject them, and that this leads to even greater resistance instead of stimulating change.

The strategy could also turn and work against change when the level of dissatisfaction and the mismatch between the teachers' expectations (whether self-established or externally imposed) and what they actually do is excessive and not under their own control, and no viable alternative is apparent. Teachers have frequent motives for dissatisfaction (Hargreaves 1996; Troman and Woods 2000): they see how the old certainties are collapsing, their teaching strategies are subjected to criticism, their authority is questioned, their roles are not those they went into the profession expecting, and reforms and proposals for innovation come one after another creating an added overload that often leads not to change but to fatigue, frustration, guilt, discouragement, disenchantment, depression, cynicism, and even abandonment of the profession.

\section{Models of Conceptual Change}

The limitations of the contradiction-based model have given rise to teacher education proposals that consider that dissatisfaction with, and self-criticism of, initial educational strategies and practices do not necessarily imply that there is a willingness to change them. The teacher has to have viable alternatives available and be capable of anticipating the actions required to put them into practice (Lucio, unpublished thesis). The models of scientific change of Lakatos and of Kuhn have for years been used as analogues for science learning by conceptual change.

For Lakatos (1983), every scientific research program has core components that are resistant to change, and the most that can be achieved by falsification is to reject auxiliary hypotheses which are easily substituted without altering the essentials. Scientific progress, for both Lakatos and the pragmatists, is produced by competition between programs, so that one would have to consider simultaneously the disadvantages of the old and the advantages of the new. Analogously, the basic aspects of teachers' theories and practices are strongly resistant to change, and when this does occur it is because the teachers have alternatives available with which they can feel more satisfied (Figure 3).

Many constructivist-based teacher education programs take as referents the four conditions of Posner et al. (1982): to determine and evaluate teachers' initial ideas, and, if they are unsatisfactory, to present new ideas that are intelligible, plausible, and useful (Hewson and Hewson 


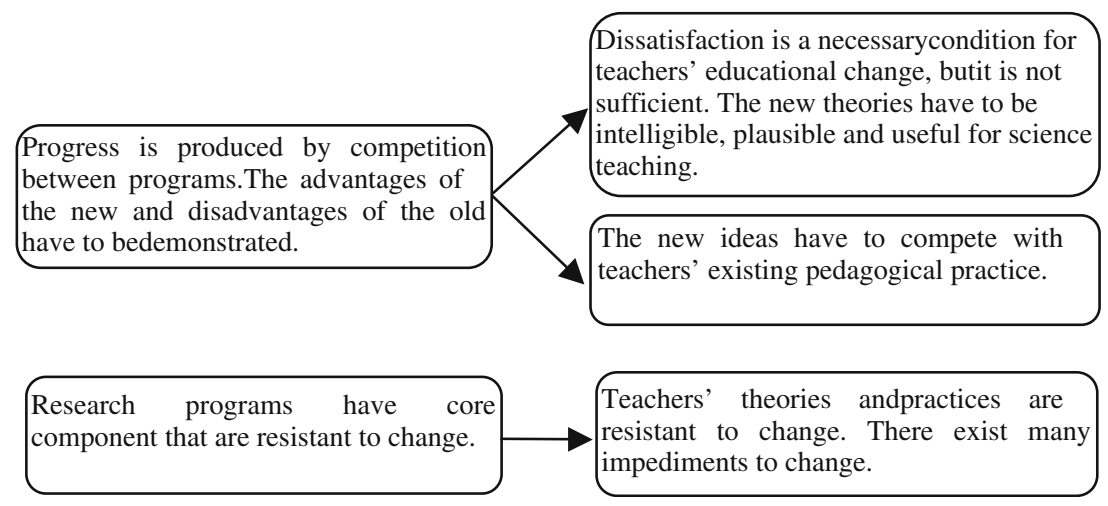

Figure 3. Analogy with the scientific research programs of Lakatos.

1989; Gunstone et al. 1993; Stofflet 1994). The strategies in teacher education encourage conceptual change through reflection on cognitive conflict (Pintó et al. 2005). While there is general agreement on the need for reflection on these initial ideas and practices, even if there is dissatisfaction with them and alternatives are available this is not enough for teachers' educational change to take place. There must also be motivation and confidence in the changes that are to be put into effect, as well as anticipation in preparing strategies for classroom action (Davis 1996; Hashweh 2003). Teachers will only change their personal theory when they perceive it as being irrelevant for their own practice, and when they have new strategies and resources available that they find useful for their everyday teaching of their specific subjects and for the learning process of their pupils (Bell and Gilbert 1994; Ritchie and Rigano 2002). In this sense, knowledge of the pupils' alternative ideas has shown itself to catalyse reflection and change on the part of teachers (Hewson et al. 1999; Lucio, unpublished thesis).

In analogy with the change-resistant core components of Lakatos, teachers do not easily change their conceptions, and even less their educational practices. They limit their changes to secondary aspects, equivalent to the auxiliary hypotheses of Lakatos (Blanco and Niaz 1998). Experienced teachers find it hard to change. In some cases this resistance is because they are satisfied with educational models that have been consolidated by professional experience, and there is coherence between their goals, conceptions, teaching behaviour, and perception of their pupils (McRobbie and Tobin 1995). In other cases, it is because there exist aspects of the educational system and the teaching community itself that reinforce traditional models and impede educational change (Tobin 1998; Hashweh 2003; Vázquez, unpublished thesis). In sum, the reason is that educational change is a complex process involving numerous obstacles and 
impedances (Davis 2003). As was observed by Delval (2002, p. 79), "changing teachers is something that is extremely difficult. For one thing, they have strongly set habits of behaviour and teaching. They teach, above all, as they themselves were taught, and when one has a certain practice it becomes extremely difficult to change it". Resistance to change in the face of new ideas is not exclusive to teachers. It is also found amongst pupils and scientists themselves (Campanario 2002).

Teachers' personal pædagogical conceptions, acquired not reflexively but naturally from their own school experiences as pupils, are a great obstacle - the hard core of Lakatos - to their educational change and ongoing education (Gil-Pérez 1991). If these problems are not taken into account in teacher education, any changes are very unlikely to be consolidated and there will be a return to the previous educational practices (Marx et al. 1998).

Initial teacher education itself can be an impediment to change if the prospective teachers have insufficient scientific and educational knowledge (Tobin and Espinet 1989). At the primary education level, the relative lack of education in scientific content may lead to 'functional illiteracy' with respect to the culture of science (Cañal 2000). This will be both a constraint on their teaching and a barrier against educational change, since the future teachers will feel insecure and lack self-confidence in teaching science. The result is that they will fall back on the textbook, dedicate less time to these topics, and find it more difficult to diagnose their pupils' alternative ideas and learning difficulties and to put changes and innovative activities into practice (Appleton 1995; Harlen and Holroyd 1997).

At the secondary education level, the academist models of teacher education - which are centred on knowledge of the material to be taught with only a bit of pedagogical knowledge and some teaching practice tacked on at the end - are not the most appropriate, not even for the scientific content itself. They are neither oriented towards teaching nor are they particularly relevant to it, and are usually presented in a form that is atomized, static, and with no global vision (Hewson et al. 1999). Moreover, they take no account of the difference between the structure of the academic discipline and that of learning (Gess-Newsome and Lederman 1995). Another of the aspects of teacher education that impedes educational change is the epistemological absolutism of science that is often transmitted (Porlán et al. 1997; Jiménez and Wamba 2003). With their pædagogical education being so sparse, the teaching behaviour of the future teachers will be decisively influenced by the methodology of their instruction in scientific content (Gess-Newsome 1999).

The paradigm shifts of Kuhn (1970) were a radical expression of change in scientific theories, where paradigm was used to mean a scientific 


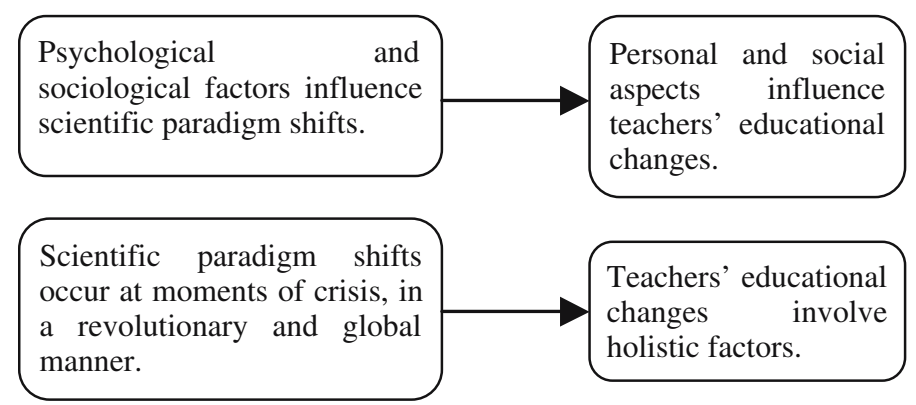

Figure 4. Analogy with Kuhn's paradigm shifts.

community's shared set of beliefs, values, and methods. In periods of normal science, scientists work within a shared paradigm, resolving the anomalies that arise within it. A shift of paradigm occurs in periods of revolutionary science, at times of crisis. The cause is rather a reconstruction of the field than any accumulation or extension of the old paradigm. The result is that the old paradigm becomes incommensurate with the new.

Although we do not believe that teachers' educational change occurs so radically, we shall refer to two aspects considered by Kuhn that seem to us to be important in establishing an analogy with the teaching community the importance of personal and contextual aspects in scientific change, and the holistic nature of scientific theories. Analogously (Figure 4), professional change in teachers is inseparable from their personal and social aspects, and it involves factors that also have to be analysed holistically.

To understand the processes of teachers' educational change, one must take the personal dimension into account (Marcelo 1994) and consider not only the teachers' capacity to change, but also whether their feelings, motivation, willingness, commitment, and emotional stability allow them to make the change effective (Hargreaves 1996). Every teacher has to identify the problematic facets of their own teaching, analyse the personal psychological effects of their situation, and be aware of the difficulties and risks involved both in adopting changes and in not doing so (Bell and Gilbert 1994). These aspects are closely related to a teacher's self-esteem, since change implies recognizing that something can be done better than it is being done at present. Elliot (1993), from an action research standpoint, considers an indispensable condition for teachers to initiate a process of change in their educational practice to be that they learn to control and tolerate a certain loss of self-esteem. The balance between loss and strengthening of self-esteem is very fragile. We therefore believe that, while critical analyses are needed, one must beware of falling into pessimism. The teacher's positive aspects must be valued for what they are, and change must be built on them as the foundation, since a strengthening of self-esteem 
and of the concept of oneself usually provides the security needed to initiate and consolidate changes (Copello and Sanmartí 2001; Reyes et al. 2001; Zembylas 2002). A focus only on the negative, and an excessive loss of self-esteem, could lead to a paralyzing situation of impotence and frustration.

Social aspects are also fundamental. The teacher is an integral part of the community of a school, and it is very difficult for change to be individually implemented, and even more so for it to be consolidated, against the current of that school's educational 'culture' and socially accepted norms (Bell 1998; Sánchez and Valcárcel 2000; Milicic et al. 2004). As noted by Hargreaves (1996, p. 280), "change takes place when the culture is acted upon, supporting it so that the teachers as a community are able to carry out the changes that benefit the pupils". Sharing problems and seeking solutions in collaboration with other teachers reinforces professional skills and provides affective and emotional support (Bell and Gilbert 1994). To be effective, however, cooperation can not be artificial or imposed, but has to encourage individual creativity (Hargreaves 1996) and respect different practices and points of view (Elliot 1993).

The class and the pupils are fundamental to the teacher's social development. Reflection on the pupils' achievements and the reinforcement and support that the teacher receives from them are a major stimulus for change (Tobin et al. 1994; Jiménez and Segura 2002), since change is closely related to "the harvesting of fruit" (Climent, unpublished thesis) in the pupils' learning process. It has even been suggested that changes in the teacher's conceptions and attitudes take place after, and not before, changes are made in teaching practice that lead to changes in the pupils' learning (Guskey 1986).

Finally, the educational administration and the parents themselves can also stimulate change in the teacher, or indeed hinder it if those changes do not respond to their conception of what is good teaching or if the initial rates of learning do not come up to their expectations (Bencze and Hodson 1999; Anderson and Helms 2001).

Another characteristic of the Kuhnian picture of scientific change that allows us to set up the analogy is the importance of holistic factors, and not just of the parts. The language that teachers use to speak about their conceptions, roles, and professional activity is not usually literal and structured, but rather symbolic and metaphoric in nature. The metaphors used in this language have shown themselves to be a means of articulating the thinking of the teaching community and of establishing 'bridges' between practical knowledge and the narrative that describes life in the classroom. They help to give an overall organization and articulation to a teacher's conceptions, roles, and practical knowledge, and allow one to discover the 
implicit referents that sustain the teacher and that have a powerful influence on his or her teaching behaviour in the classroom (Tobin and LaMaster 1995; BouJaoude 2000). There exist metaphors to define every educational environment. Examples are the teacher paradigms (reflexive, entertainer, craftsman, practical, researcher), teacher education (swimmer, ship-wrecked, novice researcher, consumer), learning (tabula rasa, sponge), the teacher's explanation (story teller), evaluation (fair judge, windows into the pupils' minds), etc.

For Tobin and Tippins (1996), metaphors may be regarded as a source of reflection, and as 'seeds' that 'will germinate' into new ideas and knowledge. Metaphors have a major affective component since teachers construct them on the basis of personal experience. When the teacher analysed in Tobin and Tippins (1996) says that his class is a 'hell', he is expressing not just an academic assessment, but something that affects his feelings and that will mark his attitude towards the class for the remainder of the course if he is unaware of what the metaphor signifies and of the negative consequences that it could have. An important aspect of educational change that is supported by many studies of science teachers (Tobin et al. 1994; McRobbie and Tobin 1995; Martínez et al. 2001) is that these teachers make changes in their conceptions and educational practices when they are able to construct new roles by way of a process of critical reflection at the same time as adopting or constructing new metaphors that are compatible with the changes.

Several studies have analysed teachers' personal metaphors (Ben-Peretz et al. 2003), many referring specifically to science teachers: traditional (transmitter, animal trainer, delivery man, shopkeeper, preacher, policeman, captain of the ship, puppeteer, watchman, training camp sergeant, etc.); constructivist (diagnostician, mediator, provocateur, cheer-leader, tour guide, facilitator, catalyst, social director, motivator, innovator, travel agent, etc.); eclectic (mother, father, brother, tutor, gardener, farmer, human being, entertainer, chameleon, doctor, etc.). To extract the richness and connotations of each of these, one would have to delve into the particular context in which they are used and into the meanings they are assigned by each teacher. For instance, the gardener metaphor could mean that the teacher 'prepares the ground' for learning, with 'fertilizer', 'irrigation', and motivation, etc., or on the contrary it could mean that the teacher 'prunes' and limits any initiative that the pupil might have.

\section{Models of Gradual Change through Internal Development}

Although the conceptual change models represented a considerable advance in science teacher education over those of technical rationality, 
they are still based more on change by substitution than on growth or internal development. Teachers do not usually make radical changes, however, but proceed by successively incorporating and putting into practice the ideas that seem to them important and approachable, and that in time they come to regard as positive (Arora et al. 2000). Such change is usually slow, but steady and gradual (Appleton and Asoko 1996; Tal et al. 2001). It also rarely involves the complete abandonment of their existing educational models in favour of new ones, but rather consists of acquisitions with partial retention (Gunstone and Northfield 1994; Valcárcel and Sánchez 2000). We believe that the processes of change in teachers can be better explained by taking as referents Laudan and Toulmin's pragmatic theories of scientific change, or Kuhn's latest versions of his theory which are close to evolutionary change: "The revolutions that have produced new divisions between fields throughout the course of scientific development closely resemble the episodes of specialization in biological evolution. The biological equivalent of revolutionary change is not mutation, as I thought for many years, but specialization" (Kuhn 1994, p. 37).

Laudan (1986) establishes the concept of research traditions (including assumptions, methodology, problems, and theories) similar to Lakatos' research programs or to Kuhn's paradigms, but now scientific change occurs continuously as problems are solved. Hence science only advances if the successive theories solve more problems than their predecessors. Change of research tradition takes place when there also exists an ontological and methodological change that affects the basic assumptions, the nature of the questions, and the goals and values.

Analogously, some constructivist-based teacher education programs (Gil-Pérez 1993; Furió and Carnicer 2002) emphasize that changes have to affect not only conceptual aspects but also methodological and attitudinal aspects and values. They propose that change should be based on research into open problematic situations in teaching and learning that are of interest to the teaching community (Figure 5).

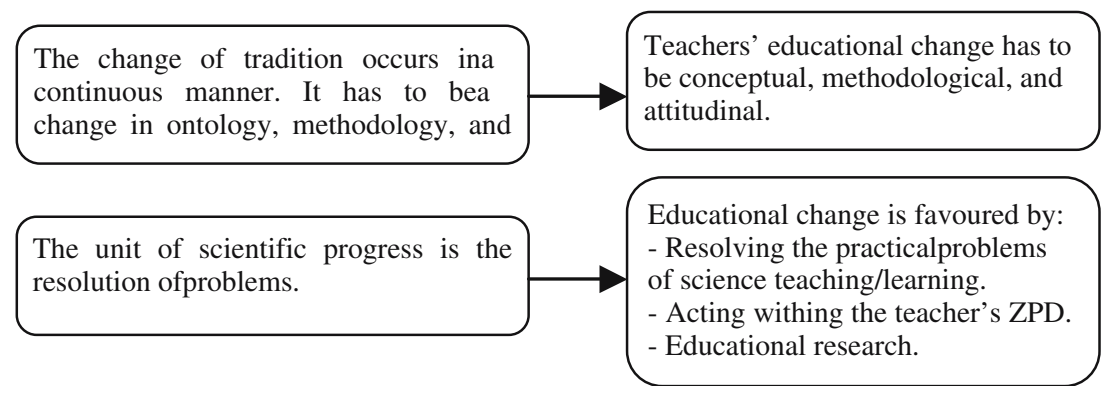

Figure 5. Analogy with Laudan's research traditions. 
It has been assumed for years that teachers' conceptions, attitudes, values, and classroom practice are related. Several studies have found, however, that, depending on the teacher and the context, these aspects are often out of phase with each other, and even plainly in contradiction, and that changes in one are not necessarily accompanied by a change in the rest (Lederman 1992; Mellado 1997, 1998; de Jong et al. 1998; Marx et al. 1998; Meyer et al. 1999). Clarke and Hollingsworth (2002) establish four interrelated domains for teachers' educational change - the personal, the external, the practical, and the consequential - involving multiple growth networks, and with changes in one domain not implying changes in the rest. Normally an epistemological change towards less dogmatic and absolutist conceptions of science and science teaching can lead to more open attitudes and to the exploration of new educational situations. But even such a change in conceptions and attitudes is no guarantee of transfer to the classroom in the form of a change in teaching practice if the teacher has no access to procedural skills and practical schemes of action in the classroom (Tobin 1993; Furió and Carnicer 2002). Unlike novice teachers, experienced teachers are usually more innovative in what they actually do in the classroom than in what they say they do, although one has been observing recently that, in some cases, the discourse of the reforms is apparently accepted without there being any concomitant change in classroom practice (King et al. 2001; Freitas et al. 2004). There is growing evidence that change is more likely to be consolidated if all its aspects, including values, are integrated and related (Sanmartí 2001).

In analogy with Laudan's model, in which the unit of scientific change is the resolution of problems, most teachers consider change to be worthwhile if it helps them to resolve the everyday practical situations that they have to face together with their pupils (Hargreaves 1996). This is a concept that is closely related to the utility of conceptual change models. There are three standpoints from which the resolution of problematic situations may be approached.

The first is that, for a teacher, pedagogical activities and practice depend largely on the subject that is being taught, and that the problematic situations of teaching and learning are problematic precisely because of the subject matter (Stodolsky 1991). The "pedagogical content knowledge" construct due to Shulman (1986) - knowledge that is specific to how each particular subject is taught, and a form of reasoning and educational action by means of which teachers transform the subject matter into representations that are comprehensible to the pupils - have been the impulse behind many studies of science teachers (Gess-Newsome and Lederman 1999). This has led to a consolidation of the didactics of specific areas of 
teaching, since change in the teachers is developed on particular content, not in the abstract (Gunstone and Northfield 1994).

The second, more psychological, standpoint is based on the studies of Vygotsky (1979) - in particular on the concept of zone of proximal development (ZPD). This concept was developed for learning, but it has a potentially generic applicability. The problematic situations with greatest capacity for change are those which lie within a teacher's ZPD. Then the teacher is motivated because there is the expectation of being able to resolve the situation (Jones et al. 1998; Ash and Levitt 2003; Lucio, unpublished thesis), and he or she sees the process of change as a stimulating and useful challenge, not as an unsolvable and discouraging problem (Bell 1998).

The third defends the encouragement of research into important problems and situations of science teaching and learning that are of interest to teachers. The relationship between research and educational practice is a central theme in both the development of science teaching and the professional development of teachers (Pro 1999), and there is sufficient evidence of the benefits of research strategies. However, the results of studies carried out by experts who themselves are outside primary and secondary schools hardly ever reach the classroom, even though these studies may have been carried out 'for' teachers. The reason is the abyss between the two cultures - that of the researcher and that of the practicing teacher. Neither is there any real classroom impact of research carried out by experts 'on' teachers, when the latter act as mere informants or subjects of the study. The investigations that have the greatest capacity to add to teacher education and the greatest likelihood of influencing actual practice are not those done 'for' or 'on' teachers, but 'by' and 'with' teachers, in teams that cross disciplines and levels (Gil-Pérez 1993; Cachapuz 1995; Gil-Pérez, Furió and Gavidia 1998).

The philosophy of science of Toulmin (1972) puts forward the concept of intellectual ecology, considering that scientific theories evolve as the result of selective pressure between populations of concepts. It thereby makes an analogy between biological evolution and the construction of scientific knowledge. The ideas of science constitute concept populations under historical development, and scientific theories change by selective evolution of these populations. Starting from unresolved problems, there arise intellectual requirements or specific practices that lead to a selective pressure on the concept populations, and eventually to a development by innovation and selection in which concepts belonging to both the old and the new theories co-exist (Batista and Porlán 1999). Analogously, teachers show a tendency to some type of model, rather than neatly fitting the pure model itself. Indeed, the new components that they incorporate have to 

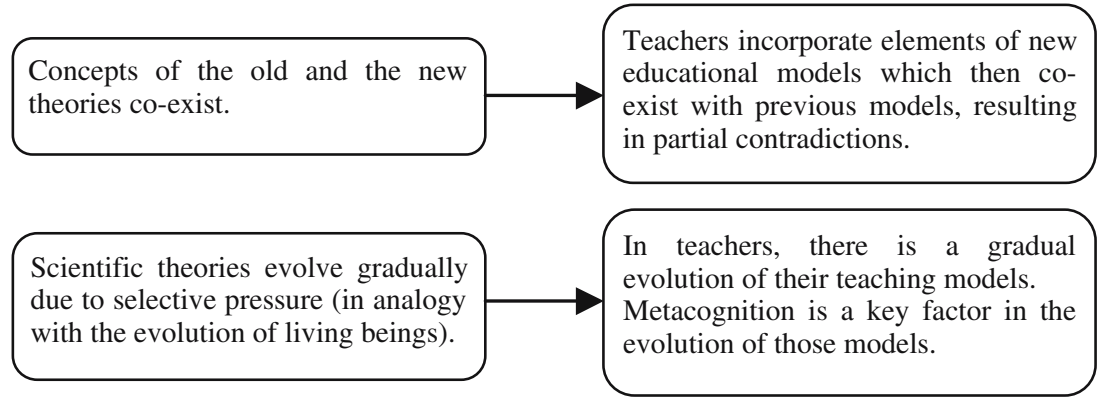

Figure 6. Analogy with Toulmin's evolutionism.

co-exist with the foregoing elements, and this of course leads to partial contradictions (Figure 6).

Porlán and Rivero (1998) propose an evolutionary framework for teacher education. This is organized around major problems in the practice of science teaching, starting from the traditional educational models, passing through intermediate levels dominated by spontaneist and technological tendencies, and having the most innovative alternative models as the level of reference. Valcárcel and Sánchez (2000) also propose progressive levels for teacher education: a first level in which the focus is on motivating, energizing, questioning, and modelling through case studies; a second level, with more emphasis on curricular development and educational research; and a third level of consolidation, with participation in collaborative projects of research and innovation.

While modelling is an extraordinarily useful instrument to help understand and guide what is thought and what is done in the classroom, in our opinion it has to avoid the determinist temptation of imposing an external direction on the evolutionary process towards an ideal model of teaching. Otherwise, besides losing the correspondence with biological evolution which is neither deterministic nor teleological, it would run the risk of standardizing and pigeon-holing good teaching outside the personal and social context of each individual teacher. As Kuhn (1994) noted in his last stage, scientific development should be seen as a process pushed from behind (evolution from something), and not pulled from in front (not evolution towards something).

In this sense, taking a metacognitive standpoint, Lucio (unpublished thesis) proposes the progressive evolution in teachers' reflection from levels that are acritical or that have external attributions, through levels of reflection that are progressively more internalized and committed, to levels of self-regulatory metacognitive reflection. Also Vázquez (unpublished thesis) considers that the professional development of science teachers will not take place by going from one set of models to another, but by reaching a greater 
complexity both in their reflection and in how they teach, passing from a more technical dimension to others that are more practical and critical.

Teachers' educational change is governed by internal, complex, autonomous dynamics that are closely related to the context, and are not subject to ideal external models. If one had to make an analogy with physics, the dynamics of teachers' educational change would seem to be nearer the self-organizing processes of the physics of chaos than to the classical physics of ideal deterministic models. A line that seems very interesting to us is the relationship between teachers' educational change and metacognition. Here the focus is on the development of metacognitive skills that facilitate understanding the cognitive processes themselves, reflection in and about action, and awareness of the causes of both the difficulties that arise in teaching practice and of the obstacles to educational change, and that thereby enable self-regulation and control of that change (Gunstone and Northfield 1994; Copello and Sanmartí 2001; Hashweh 2003; Lucio, unpublished thesis). While the control and self-regulation of the evolution, speed, and nature of the changes doubtless require far more time and support than just the superficial execution of external guidelines, they have proved to be fundamental in consolidating improvements in classroom practice (Bell and Gilbert 1994).

\section{Implications for Science Teacher Education}

There is growing recognition that teacher education and educational change are strongly dependent and two facets of the same thing (Carr 1990; Marcelo 1994; Delval 2002). In the following, we shall highlight certain aspects of the analogy developed in this article that we consider important for the professional development of experienced science teachers. The stages of initial teacher education and beginning teaching would require specific treatment, and we shall only refer to them as to what they imply for experienced teachers' subsequent resistance to educational change.

\subsection{GROWTH AND GRADUAL EVOLUTION OF THE TEACHER RATHER THAN CHANGE BY SUBSTITUTION (TOULMIN)}

For experienced teachers, ongoing education can not be designed and presented as a 'change', but rather as an internal process of 'growth' and 'gradual development' based on what they already think and do (Day 1999), on the real problems of science teaching and learning, on their everyday concerns, and on the context in which they work. The prime aim is to support and enhance their motivation, confidence, willingness, collaboration, and commitment to their own professional development. 
Professional development is stimulated by successive processes of metacognitive self-regulation, based on the teachers' reflection, comprehension, and monitoring of what they think, feel, and do, and of the changes that they put into effect. This involves awareness of what problems of teaching and learning might be improvable, elaborating new activities, materials, and teaching proposals (Powell and Anderson 2002; Sassi et al. 2005), putting them into practice in the appropriate context, successive reflection on their teaching and on the results in the pupils' learning, and comparing their practices with other cases to again revise and self-regulate them (Marx et al. 1998). In this process, teachers evolve from their own individual situation and context towards a greater complexity in reflection and in how they teach science (Vázquez, unpublished thesis).

\subsection{THE CONSTRUCTIVIST-BASED PROGRAMS OF SCIENCE TEACHER EDUCATION (LAKATOS)}

Science teaching research has been dominated since the 80 s by the constructivist paradigm, which has led to considerable progress in many aspects of the teaching and learning of science. There is currently a debate in the international community on the origins, foundations, types, and future possibilities of the development of constructivism (Gil-Pérez et al. 2002; Niaz et al. 2003) which will indubitably redound in a more solid basis for science teaching and in a greater richness of approaches.

Matthews $(1994,1997)$ has criticized the epistemological foundation of constructivism with its marked empiricist aspects in the individual construction of scientific knowledge in the learning of science, and its neglect of the role of idealization in the construction of theoretical concepts that are not coincident with personal experiences. The situation is different, however, with respect to the way in which teachers learn to teach science, and the subsequent change or evolution of their teaching models, because teachers have no universal referents available in science teaching equivalent to scientific theories.

Constructivist-based programs for the professional development of teachers have evolved from the initial conceptual change by substitution through competition towards more gradual change. The authors of the four conditions of conceptual change themselves in subsequent teacher education programs progressively incorporated such new concepts as the changing status of ideas and conceptual ecology, and introduced perspectives shared with other orientations such as action research or metacognition (Hewson 1993; Hewson et al. 1999). With these additions, we consider that the constructivist paradigm constitutes an appropriate theoretical framework for science teacher education. 
Another fundamental aspect of Lakatos that has to be borne in mind is resistance to change. The beliefs and practical knowledge of experienced teachers are very stable and resistant to change, having been formed and consolidated over the course of their education and careers (Appleton and Asoko 1996). Neither do in-service teachers have much time available for ongoing education courses. These imply for them extra effort, even work overload, for something that they often consider irrelevant to what they have to do every day in their classroom (Munby and Russell 1998).

One very important stage is the initiation to teaching during the first years of their career, when the novice teachers are subjected to tension, dilemmas, and overload, and when their teaching routines and strategies are fixed. We believe, however, that the origin of the hard core of teachers' subsequent resistance to change may lie in their initial teacher education. For this resistance not to develop, prospective teachers will have to learn to understand educational changes and also to understand and self-regulate changes in themselves. The challenge is to endow them with the criteria, the creative and critical thinking, and the tools needed to help them construct an effective self-regulatory system so that they can continue educating themselves autonomously throughout their careers as teachers (Sanmartí 2001). Initial teacher education has to integrate academic knowledge, personal conceptions, and practical knowledge, and contribute to the prospective teachers' generating their own pædagogical content knowledge. Since propositional academic knowledge is not transferred directly into practice (Bryan and Abell 1999), teacher education has to provide students with the opportunity - via a metacognitive process of reflection - of becoming aware of their own conceptions, attitudes, and classroom practice when they are teaching their particular subject matter (Mellado et al. 1998). They will then be able to self-regulate and re-structure these facets of their teaching, and progressively develop a personal teaching model (Sanmartí 2001).

\subsection{THE RESOLUTION OF THE PROBLEMS OF SCIENCE TEACHING AND LEARNING AS A MOTOR OF CHANGE (LAUDAN)}

In analogy with Laudan's model, in which the unit of scientific change is the resolution of problems, most teachers consider change to be worthwhile if it helps them to resolve the everyday practical situations that they have to face together with their pupils. Gil-Pérez (1993) proposes that change should be based on research into open problematic situations in teaching and learning that are of interest to the teaching community.

Academic knowledge, conceptions, attitudes, values, and the actual practices of teachers when they are teaching their subjects have to be integrated into these open problematic situations. The axis of their professional 
development, however, has to be science education, since the content to be taught conditions both the teacher's role and the teaching strategies (Tobin and McRobbie 1999). Action research in collaboration with other teachers into important situations and problems in science teaching and learning, and which are of interest for their own classes - in particular longitudinal studies of their own case - is an extraordinarily effective strategy for professional development in the medium and long terms (Baird et al. 1991; Lyons et al. 1997; Roth 1998). These investigations are done 'by' and 'with' teachers, in teams that cross disciplines and levels, where the teachers are not consumers of external knowledge, but co-producers and agents of change in the problems that really concern them in their classes (Gil-Pérez et al. 1998).

Tutoring novice teachers or prospective teachers in their practice teaching can be turned into a positive experience of ongoing education and professional development, both for primary or secondary school teachers and for university instructors (Roth et al. 2001). For the tutor, it can involve collaborating with teachers of different levels, elaborating joint teaching or research projects, analyzing science teaching and learning situations in a real class context, and many other activities that help the teacher to escape from isolation and to work in collaboration (Ash and Levitt 2003).

\subsection{TEACHERS' PERSONAL AND SOCIAL DEVELOPMENT TOGETHER WITH THEIR PROFESSIONAL DEVELOPMENT (KUHN)}

Professional development has to go together with personal and social development (Bell and Gilbert 1994), taking affective aspects into account, reinforcing the teacher's self-esteem, encouraging constructive collaboration, strengthening the culture of the corresponding school, and building on the good practice that the teachers are already carrying out (Hargreaves 1996). As noted by Day (1999), change is not just a matter of the head, but also of the heart. It will be difficult to put changes into effect unless they are compensated affectively and contribute to greater personal job satisfaction. Teacher education programs have to treat the teacher as an integral member of a group, providing collective development experiences and encouraging collaboration. In sum, they must consider the school as being the most suitable place for professional development and as the unit for change (Valcárcel and Sánchez 2000; Anderson and Helms 2001; Reyes et al. 2001; Marcelo 2002; Ritchie and Rigano 2002; Davis 2003; Sassi et al. 2005). This requires time and much sustained support before the teacher can see the improvement in the pupils' learning and perceive ongoing education as a meaningful experience personally, for his or her classes, and for the school (Sánchez and Valcárcel 2000; Tal et al. 2001; Peers et al. 2003). 


\section{Final Thoughts}

Over the course of this article, we have reviewed the results of studies that have contributed data about the process of educational change in science teachers. We organized the information by setting up analogies with the process of scientific change according to different theories of the philosophy of science, and analysed and evaluated the contributions of the different models. Many of the characteristics of the educational change of science teachers we found to be not exclusive, but complementary, forming a network that, at least for us, helped understand this complex process. While ours may be a somewhat eclectic solution, we could find no single theory that explained the complexity of the change. We believe, however, that this represents no cause for concern since, as observed by Shulman (1986), there is no reason in education for there to exist dominant and exclusive paradigms in the Kuhnian sense. Indeed, the co-existence of apparently divergent schools of thought, far from being a weakness of development, may rather be the natural state and a reflection of maturity, allowing one to better understand the multiple nuances in the complexity of teaching (Tobin 1998).

\section{Acknowledgements}

This work was financed by Research Project BSO2003-03603 of the Ministry of Science and Technology (Spain). A first version of this paper appeared in Spanish in 2003 in the journal Enseñanza de las Ciencias and is published here with permission.

\section{References}

Abell, S.K. \& Pizzini, E.L.: 1992, 'The Effect of a Problem Solving In-Service Program on the Classroom Behaviors and Attitudes of Middle School Science Teachers', Journal of Research in Science Teaching 29(7): 649-667.

Adúriz-Bravo, A.: 2001, 'Relaciones entre la didáctica de las ciencias experimentales y la filosofía de la ciencia', in Perales F.J. (ed.), et al. Congreso Nacional de Didácticas Específicas. Las didácticas de las áreas curriculares en el siglo XXI (vol I), Grupo Editorial Universitario, Granada (Spain), pp. 478-491.

Anderson, R.D. \& Helms, J.V.: 2001, 'The Ideal of Standards and the Reality of Schools: Needed Research', Journal of Research in Science Teaching 38(1): 3-16.

Appleton, K.: 1995, 'Student Teachers' Confidence to Teach Science: Is More Science Knowledge Necessary to Improve Self-Confidence?', International Journal of Science Education 19(3): 357-369. 
Appleton, K. \& Asoko, H.: 1996, 'A Case Study of a Teacher's Progress Toward Using a Constructivist View of Learning to Inform Teaching in Elementary Science', Science Education 80(2): 165-180.

Arora, A.G., Kean, E. \& Anthony, J.L.: 2000, 'An Interpretative Study of a Teacher's Evolving Practice of Elementary School Science', Journal of Science Teacher Education 11(1): $1-25$.

Ash, D. \& Levitt, K.: 2003, 'Working within the Zone of Proximal Development: Formative Assessment as Professional Development', Journal of Science Teacher Education 14(1): 23-48.

Baird, J.R., Fensham, P.J, Gunstone, R.F. \& White, R.T.: 1991, 'The Importance of Reflection in Improving Science Teaching and Learning', Journal of Research in Science Teaching 28(2): 163-182.

Batista, J. \& Porlán, R.: 1999, 'La epistemología evolucionista de Stephen Toulmin y la enseñanza de las ciencias', Investigación en la Escuela 39, 17-26.

Bell, B.: 1998, Teacher Development in Science Education, in Fraser B.J. and Tobin K. K. (eds.) International Handbook of Science Education, Kluwer A.P., Dordrecht, pp. 681-694.

Bell, B. \& Gilbert, J.: 1994, 'Teacher Development as Professional, Personal and Social Development', Teaching and Teacher Education 10(5): 483-497.

Bencze, L. \& Hodson, D.: 1999, 'Changing Practice by Changing Practice: Toward more Authentic Science and Science Curriculum Development', Journal of Research in Science Teaching 36(5): 521-539.

Ben-Peretz, M., Mendelson, N. \& Kron, F.W.: 2003, 'How Teachers in Different Educational Contexts View their Roles', Teaching and Teacher Education 19(2): 277-290.

Bermejo, M.L., Fajardo, M.I. \& Mellado, V.: 2002, 'Teaching and Learning Sciences for Blind and Visually Impaired Students', Journal of Science Education for Students with Disabilities 9, 15-21.

Blanco, R. \& Niaz, M.: 1998, 'Baroque Tower on a Gothic base: A Lakatosian Reconstruction of Students' and Teachers' Understanding of Structure of the Atom', Science and Education 7(4): 327-360.

Boujaoude, S.: 2000, 'Conceptions of Science Teaching Revealed by Metaphors and Answers to Open-Ended Questions', Journal of Science Teacher Education 11(2): 173-186.

Bryan, L.A. \& Abell, S.K.: 1999, 'Development of Professional Knowledge in Learning to Teach Elementary Science', Journal of Research in Science Teaching 36(2): 121-139.

Burbules, N.C. \& Linn, M.C.: 1991, 'Science Education and Philosophy of Science: Congruence or Contradiction?', International Journal of Science Education 13(3): 227-241.

Cachapuz, A.: 1995, Da investigação sobre e para professores à investigação com e pelos professores de Ciências, in Blanco L.J. and Mellado V. (eds.) La Formación del Profesorado de Ciencias y Matemáticas en España y Portugal, Diputación Provincial, Badajoz (Spain), pp. 243-254.

Campanario, J.M.: 2002, 'The Parallelism between Scientists' and Students' Resistance to New Scientific Ideas', International Journal of Science Education 24(10): 1095-1110

Cañal, P.: 2000, 'El conocimiento profesional sobre las ciencias y la alfabetización científica en primaria', Alambique 24, 46-56.

Carr, W.: 1990, 'Cambio educativo y desarrollo profesional', Investigación en la Escuela 11, $3-11$

Clarke, D. \& Hollingsworth, H.: 2002, 'Elaborating a Model of Teacher Professional Growth', Teaching and Teacher Education 18(8): 947-967.

Clemison, A.: 1990, 'Establishing an Epistemological Base for Science Teaching in the Light of Contemporary Notions of the Nature of Science an of how Children Learn Science', Journal of Research in Science Teaching 27(5): 429-455. 
Cobb, P., Wood, T. \& Yackel, E.: 1991, 'Analogies from the Philosophy and Sociology of Science for Understanding Classroom Life', Science Education 75(1): 23-44.

Copello, M.I. \& Sanmartí, N.: 2001, 'Fundamentos de un modelo de formación permanente del profesorado de ciencias centrado en la reflexión dialógica sobre las concepciones y las prácticas', Enseñanza de las Ciencias 19(2): 269-283.

Cudmani, L., Pesa, M.A. \& Salinas, J.: 2000, 'Hacia un modelo integrador para el aprendizaje de las ciencias', Enseñanza de las Ciencias 18(1): 3-13.

Davis, K.S.: 2003, "“Change is Hard": What Science Teachers are Telling us about Reform and Teacher Learning and Innovative Practices', Science Education 87(1): 3-10.

Davis, N.T.: 1996, 'Looking in the Mirror: Teachers' use of Autobiography and Action Research to Improve Practice', Research in Science and Education 26(1): 23-32.

Day, Ch.: 1999, Developing Teachers, the Challenges of Lifelong Learning, Falmer Press, London

De Jong, O., Korthagen, F. \& Wubbels, T. : 1998, 'Research on Science Teacher Education in Europe Teacher Thinking and Conceptual Change', in: B.J. Fraser B.J. and K. Tobin (eds.), International Handbook of Science Education, Kluwer A.P., Dordrecht, pp. 745-758.

Delval, J.: 2002, 'Entrevista a Juan Delval, realizada por P', Cañal', Investigación en la Escuela 43, $71-80$

Elliot, J.: 1993, El cambio educativo desde la investigación-acción, Morata, Madrid (Spain).

Estany, A.: 1990, Modelos de cambio cientifico, Crítica, Barcelona (Spain).

Estany, A.: 1993, Introducción a la filosofía de la ciencia, Crítica, Barcelona (Spain).

Freitas, M.I., Jiménez, R. \& Mellado, V.: 2004, 'Solving Physics Problems: The Conceptions and Practice of an Experienced Teacher and an Inexperienced Teacher', Research in Science Education 34(1): 113-133.

Fullan, M.: 1991, The New Meaning of Educational Change, Teacher College Press, Chicago.

Furió, C. \& Carnicer, J.: 2002, 'El desarrollo profesional del profesor de ciencias mediante tutorías de grupos cooperativos. Estudio de ocho casos', Enseñanza de las Ciencias 20(1): 47-73.

Garret, R.M., Satterly, D., Gil-Pérez, D. \& Martínez, J.: 1990, 'Turning Exercises into Problems: An Experimental Study with Teachers in Training', International Journal of Science Education 12(1): 1-12.

Gess-Newsome, J.: 1999, Secondary Teachers' Knowledge and Beliefs about Subject Matter and their Impact on Instruction, in Gess-Newsome J. and Lederman N. (eds.) Examining Pedagogical Content Knowledge, Kluwer A.P., Dordrecht, pp. 51-94.

Gess-Newsome, J. \& Lederman, N.G.: 1995, 'Biology Teachers' Perceptions of Subject Matter Structure and its Relationship to Classroom Practice', Journal of Research in Science Teaching 32(3): 301-325.

Gess-Newsome, J. \& Lederman, N.G.: 1999, Examining Pedagogical Content Knowledge, Kluwer A.P., Dordrecht.

Gil-Pérez, D.: 1991, 'Qué hemos de saber y saber hacer los profesores de ciencias', Enseñanza de las Ciencias 9(1): 69-77.

Gil-Pérez, D.: 1993, 'Contribución de la historia y de la filosofía de las ciencias al desarrollo de un modelo de enseñanza/aprendizaje', Enseñanza de las Ciencias 11(2): 197-212.

Gil-Pérez, D., Beléndez, A., Martín, A. \& Martínez, J.: 1991, 'La formación del profesorado universitario de materias científicas: contra algunas ideas y comportamientos de "sentido común", Revista Interuniversitaria de Formación del Profesorado 12: 43-48.

Gil-Pérez, D., Furió, C. \& Gavidia, V.: 1998, 'El profesorado y la reforma educativa en España', Investigación en la Escuela 36: 49-64.

Gil-Pérez, D., Guisasola, J., Moreno, A., Cachapuz, A., Pessoa, A.M., Martínez, J., Salinas, J., Valdés, P., González, E., Gené, A., Dumás-Carré, A., Tricárico, H. \& Gallego, R.: 
2002, 'Defending Constructivism in Science Education', Science and Education 11(6): 557571.

Gilbert, J.K.: 1999, 'On the Explanation of Change in Science and Cognition', Science and Education 8(5): 543-557.

Gunstone, R.F. \& Northfield, J.R.: 1994, 'Metacognition and Learning to Teach', International Journal of Science Education 16(5): 523-537.

Gunstone, R.F., Slattery, M., Baird, J.R. \& Northfield, J.R.: 1993, 'A Case Study Exploration of Development in Preservice Science Teachers', Science Education 77(1): 47-73.

Guskey, T.R.: 1986, 'Staff Development and the Process of Teacher Change', Educational Researcher 15(5): 5-12.

Harlen, W. \& Holroyd, C.: 1997, 'Primary Teachers' Understanding of Concepts of Science: Impact on Confidence and Teaching', International Journal of Science Education 19(1): 93-105.

Hargreaves, A.: 1996, Profesorado, cultura y modernidad, Morata, Madrid.

Hashweh, M.Z.: 2003, 'Teacher Accommodative Change', Teaching and Teacher Education 19(4): 421-434.

Hewson, P.W.: 1993, Constructivism and Reflective Practice in Science Teacher Education, in Montero M.L. and Vez J.M. (eds.) Las didácticas especificas en la formación del profesorado., Tórculo, Santiago, Spain, pp. 259-275.

Hewson, P.W. \& Hewson, M.G.: 1989, 'Analysis and Use of a Task for Identifying Conceptions of Teaching Science', Journal of Educational for Teaching 15(3): 191-209.

Hewson, P.W., Tabachnick, B.R., Zeichner, K.M. \& Lemberger, J.: 1999, 'Educating Prospective Teachers of Biology: Findings, Limitations, and Recommendations', Science Education 83(3): 373-384.

Jiménez, E. \& Segura, P.: 2002, Ideas de los profesores de física sobre la enseñanza y la solución de problemas en el bachillerato, University of La Laguna, Tenerife (Spain), pp. 164-172XX Encuentros de didáctica de las ciencias experimentales.

Jiménez, R. \& Wamba, A.M.: 2003, 'Es posible el cambio de modelos didácticos? Obstáculos en profesores de Ciencias Naturales de educación secundaria', Investigación en la Escuela 17(1): 113-131.

Jones, M.G., Rua, M.J. \& Carter, G.: 1998, 'Science Teachers' Conceptual Growth within Vygotsky's Zone of Proximal Development', Journal of Research in Science Teaching 35(9): 967-985.

King, K., Shumow, L. \& Lietz, S.: 2001, 'Science Education in an Urban Elementary School: Case Studies of Teacher Beliefs and Classroom Practices', Science Education 85(2): 89-110.

Kraft, V.: 1977, El Círculo de Viena, Taurus, Madrid.

Kuhn, T.: 1970, The Structure of Scientific Revolutions, 2nd edn. Chicago University Press.

Kuhn, T.: 1994, 'El camino desde 'La estructura"', Arbor 584, 27-47.

Lakatos, I.: 1983, La metodología de los programas de investigación cientifica, Alianza Editorial, Madrid (Spain).

Laudan, L.: 1986, El progreso y sus problemas Hacia una teoría del progreso científico, Ediciones Encuentro, Madrid (Spain).

Lederman, N.G.: 1992, 'Students' and Teachers' Conceptions of the Nature of Science: A Review of the Research", Journal of Research in Science Teaching 29(4): 331-359.

Lyons, L.L., Freitag, P.K. \& Hewson, P.W.: 1997, 'Dichotomy in Thinking, Dilemma in Actions: Researcher and Teacher Perspectives on a Chemistry Teaching Practice', Journal of Research in Science Teaching 34(3): 239-254.

Marcelo, C.: 1994, Formación del profesorado para el cambio educativo, PPU, Barcelona.

Marcelo, C.: 2002, 'Los profesores como trabajadores del conocimiento Certidumbres y desafíos para una formación a lo largo de la vida', Educar 30, 27-56. 
Martínez, M.A., Sauleda, N. \& Huber, G.H.: 2001, 'Metaphors as Blueprints of Thinking about Teaching and Learning', Teaching and Teacher Education 17(8): 965-977.

Marx, R.W., Freeman, J., Krajcik, J. \& Blumenfed, P.: 1998, Professional Development of Science Education, in Fraser B.J. and Tobin K. (eds.) International Handbook of Science Education, Kluwer A.P., Dordrecht, pp. 667-680.

Matthews, M.R.: 1992, 'History, Philosophy, and Science Teaching: A Present Rapprochement', Science and Education 1(1): 11-47

Matthews, M.R.: 1994, 'Vino viejo en botellas nuevas: Un problema con la epistemología constructivista', Enseñanza de las Ciencias 12(1): 79-88.

Matthews, M.R.: 1997, 'Introductory Comments on Philosophy and Constructivism in Science Education', Science and Education 6(1-2): 5-14.

Matthews, M.R.: 2004a, 'Thomas Kuhn's Impact on Science Education: What Lessons can be Learned?', Science Education 88(1): 90-118.

Matthews, M.R.: 2004b, 'Reappraising Positivism and Education: The Arguments of Philipp Frank and Herbert Feigl', Science and Education 13(1/2): 7-39.

McRobbie, C. \& Tobin, K.: 1995, 'Restraints to Reform: The Congruence of Teacher and Students Actions in a Chemistry Classroom', Journal of Research in Science Teaching 32(4): 373-385.

Mellado, V.: 1997, 'Preservice Teachers' Classroom Practice and their Conceptions of the Nature of Science', Science and Education 6(4): 331-354.

Mellado, V.: 1998, 'The Classroom Practice of Preservice Teachers and their Conceptions of Teaching and Learning Science', Science Education 82(2): 197-214.

Mellado, V.: 2003, 'Cambio didáctico del profesorado de ciencias experimentales y filosofía de la ciencia', Enseñanza de las Ciencias 21(3): 343-358.

Mellado, V. \& Carracedo, D.: 1993, 'Contribuciones de la filosofía de la ciencia a la didáctica de las ciencias', Enseñanza de las Ciencias 11(3): 331-339.

Mellado, V., Blanco, L.J. \& Ruiz, C.: 1998, 'A Framework for Learning to Teach Science in Initial Primary Teacher Education', Journal of Science Teacher Education 9(3): 195-219.

Meyer, H., Tabachnick, B.R., Hewson, P.W., Lemberger, J. \& Park, H.: 1999, 'Relationship Between Prospective Elementary Teachers' Classroom Practice and their Conceptions of Biology and of Teaching Science', Science Education 83(3): 323-346.

Milicic, B., Utges, G., Salinas, B. \& Sanjosé, V.: 2004, 'Creencias, concepciones y enseñanza en la Universidad: Un estudio de caso de desarrollo profesional colaborativo centrado en un profesor de física', Revista española de Pedagogía. 229, 377-389.

Mitchener, C.P. \& Anderson, R.D.: 1989, 'Teachers' Perspective: Developing an Implementing an STS Curriculum', Journal of Research in Science Teaching 26(4): 351-369.

Munby, H. \& Russell, T.: 1998, Epistemology and Context in Research on Learning to Teach Science, in Fraser B.J. and Tobin K. (eds.) International Handbook of Science Education., Kluwer A.P., Dordrecht, pp. 643-665.

Niaz, N., Abd-el Khalick, F., Benarroch, A., Cardellini, L., Laburu, C.E., Marín, N., Montes, L.A., Nola, R., Orlik, Y., Schamann, L.C., Tsai, C.-C. \& Tsaparlis, G.: 2003, 'Constructivism: Defense or a Continual Critical Appraisal. A Response to Gil-Pérez et al.', Science and Education 12(8): 787-797.

Nussbaum, J.: 1989, 'Classroom Conceptual Change: Philosophical Perspectives', International Journal of Science Education 11((special issue)): 530-540.

Peers, Ch.E., Diezmann, C.M. \& Watters, J.J.: 2003, 'Supports and Concerns for Teacher Professional Growth During the Implementation of a Science Curriculum Innovation', Research in Science Education 33(1): 89-110. 
Perales, F.J.: 1998, 'La formación del profesorado universitario en didáctica de las ciencias experimentales Desde el inmovilismo a la búsqueda de alternativas', Revista de Educación de la Universidad de Granada 11, 345-354.

Pintó, R., Couso, D. \& Gutiérrez, R.: 2005, 'Using Research on Teachers' Transformations of Innovations to Inform Teacher Education The Case of Energy Degradation', Science Education 89(1): 38-55.

Philipp, D.: 2004, 'Two Decades After: 'After the Wake: Postpositivistic Educational Thought", Science and Education 13(1/2): 67-84.

Piaget, J.: 1970, Genetic Epistemology, Columbia University Press, New York.

Popper, K.R.: 1983, Conjeturas y refutaciones El desarrollo del pensamiento cientifico, Paidos, Buenos Aires.

Porlán, R. \& Rivero, A.: 1998, El conocimiento de los profesores, Diada, Seville (Spain).

Porlán, R., Rivero, A. \& Martín, R.: 1997, 'Conocimiento profesional y epistemología de los profesores-I: teoría, métodos e instrumentos', Enseñanza de las Ciencias 15(2): 155-171.

Posner, G.J., Strike, K.A., Hewson, P.W. \& Gertzog, A.: 1982, 'Accommodation of a Scientific Conception: Toward a Theory of Conceptual Change', Science Education 66(2): 211-277.

Powell, J.C. \& Anderson, R.D.: 2002, 'Changing Teachers' Practice: Curriculum Materials and Science Education Reform in the USA', Studies in Science Education 37(1): 107-136.

Pro, A.: 1999, Qué investigamos cómo lo hacemos 'A qué conclusiones llegamos: tres preguntas que hacen pensar, in Martínez C. and García S. (eds.) La didáctica de las ciencias Tendencias actuales, University of Coruña, Coruña (Spain), pp. 19-43.

Reyes, L., Salcedo, L.E. \& Perafán, G.: 2001, Acciones y Creencias IV: Análisis e interpretación de creencias de docentes de Biología y Ciencias Naturales, University Pedagógica Nacional, Bogotá (Colombia).

Ritchie, S.M. \& Rigano, D.L.: 2002, 'Discourses about a Teacher's Self-Initiated Change in Praxis: Storylines of Care and Support', International Journal of Science Education 24(10): 1079-1094.

Roth, W.M.: 1998, 'Science Teaching as Knowledgability: A Case Study of Knowing and Learning During Coteaching', Science Education 82(3): 357-377.

Roth, W.M., Tobin, K., Zimmermann, A., Bryant, N. \& Davis, Ch.: 2001, 'Lessons On and From the Dihybrid Cross: An Activity-Theoretical Study of Learning in Coteaching', Journal of Research in Science Teaching 39(3): 253-282.

Sánchez, G. \& Valcárcel, M.V.: 2000, "Qué tienen en cuenta los profesores cuando seleccionan el contenido de enseñanza? Cambios y dificultades tras un programa de formación', Enseñanza de las Ciencias 18(3): 423-437.

Sanmartí, N.: 2001, 'Enseñar a enseñar ciencias en secundaria: un reto muy complejo', Revista Interuniversitaria de Formación del Profesorado' 40: 31-48.

Sassi, E., Monroy, G. \& Testa, I.: 2005, 'Teacher Training About Real-Time Approaches: Research-Based Guidelines and Training Materials', Science Education 89(1): 28-37.

Shulman, L.S.: 1986, Paradigms and Research Programs in the Study of Teaching: A Contemporary Perspectiva, in Wittrock M.C. (eds.) Thrid Handbook of Research on Teaching., Macmillan, New York, pp. 3-36.

Stodolsky, S.S.: 1991, La importancia del contenido en la enseñanza Actividades en las clases de matemáticas y ciencias sociales, MEC-PAIDOS, Madrid (Spain).

Stofflett, R.T.: 1994, 'The Accommodation of Science Pedagogical Knowledge: The Application of Conceptual Change Constructs to Teacher Education', Journal of Research in Science Teaching 31(8): 787-810. 
Tal, R.T., Dori, Y.J., Keiny, S. \& Zoller, U.: 2001, 'Assessing Conceptual Change of Teachers Involved in STES Education and Curriculum Development. The STEMS Project Approach.', International Journal of Science Education 23(3): 247-262.

Tobin, K.: 1993, 'Referents for Making Sense of Science Teaching', International Journal of Science Education 15(3): 241-254.

Tobin, K.: 1998, Issues and Trends in the Teaching of Science, in Fraser B.J. and Tobin K. (eds.) International Handbook of Science Education, Kluwer A.P., Dordrecht, pp. 129-151.

Tobin, K. \& Espinet, M.: 1989, 'Impediments to Change: Applications of Coaching in High School Science Teaching', Journal of Research in Science Teaching 26(2): 105-120.

Tobin, K. \& Lamaster, S.U.: 1995, 'Relationships Between Metaphors, Beliefs, and Actions in a Context of Science Curriculum', Journal of Research in Science Teaching 32(3): 225-242.

Tobin, K. \& McRobbie, C.: 1999, 'Pedagogical Content Knowledge and Co-Participation in Science Classrooms', in Gess-Newsome J. and Lederman N. (eds.) Examining Pedagogical Content Knowledge, Kluwer A.P., Dordrecht, pp. 215-234.

Tobin, K. \& Tippins, D.J.: 1996, 'Metaphors as Seeds for Conceptual Change and the Improvement of Science Education', Science Education 80(6): 711-730.

Tobin, K., Tippins, D.J. \& Gallard, A.J.: 1994, Research on Instructional Strategies for Teaching Science, in Gabel D. (eds.) Handbook of Research on Science Teaching and Learning, MacMillan, New York, pp. 3-44.

Toulmin, S.E.: 1972, Human Understanding, Clarendon Press, Oxford.

Troman, G. \& Woods, P.: 2000, 'Careers Under Stress: Teacher Adaptations at a Time of Intensive Reform', Journal of Educational Change 1, 253-275.

Valcárcel, M.V. \& Sánchez, G.: 2000, La formación del profesorado en ejercicio, in Perales F.J. and Cañal P. (eds.) Didáctica de las Ciencias Experimentale, Marfil, Alcoy, pp. 557-581.

Vázquez, A., Acevedo, J.A., Manassero, M.A. \& Acevedo, P.: 2001, 'Cuatro paradigmas básicos sobre la naturaleza de la ciencia', Argumentos de Razón Técnica 4, 135-176.

Villani, A.: 2001, 'Filosofía da ciencia e ensino de ciência: Uma analogía', Ciencia \& Educaçao 7(2): 169-181.

Vygotsky, L.: 1979, El desarrollo de los procesos psicológicos superiores, Grijalbo, Barcelona (Spain).

Wildy, H. \& Wallace, J.: 1995, 'Understanding Teaching or Teaching for Understanding: Alternative Frameworks for Science Classrooms', Journal of Research in Science Teaching 32(2): 143-156.

Zembylas, M.: 2002, 'Constructing Genealogies of Teachers' Emotions in Science Teaching', Journal of Research in Science Teaching 39(1): 79-103. 